\title{
Monika Pasiecznik
}

Uniwersytet Wrocławski,

Wydział Nauk Historycznych i Pedagogicznych,

Instytut Muzykologii

ORCID: 0000-0003-1792-8510

\section{Nowa Muzyka i przyjemność w serii utworów audiowizualnych ASMR Neo Hülckera}

DOI: $10.14746 / \mathrm{rfn} .2020 .21 .5$

Nowa Muzyka rozwijała się w drugiej połowie XX wieku w dużej mierze pod wpływem filozofii Theodora W. Adorna ${ }^{1}$. Jej znaczenie, zdaniem filozofa, polega na krytyce społecznej, którą kompozytor dokonuje poprzez radykalną innowację artystyczną i dystans wobec czyichkolwiek oczekiwań. Słynna Filozofia nowej muzyki, którą pilnie czytały pokolenia kompozytorów i krytyków, ukazała się krótko po wielkiej katastrofie II wojny światowej. Adorno nadał w niej sens eksperymentom muzycznym, łącząc je z krytyką społeczną - legitymizował innowacje muzyczne jako formę oporu przeciwko społeczeństwu odpowiedzialnemu za Holokaust. Ceną, jaką Nowa Muzyka musiała jednak zapłacić za swą bezkompromisowość, była społeczna alienacja: „Nowa muzyka jest już z góry nastawiona na to, że nie będzie słuchana"2. Dialektyczna moc Nowej Muzyki była jednak odwrotnie proporcjonalna do jej popularności: im bardziej Nowa Muzyka była wyobcowana i niesłuchana, tym głębszą krytykę społeczną reprezentowała.

W całym tekście stosuję tradycyjną niemiecką pisownię „Nowa Muzyka” wielkimi literami w formie nazwy własnej, dla podkreślenia odrębności tej dziedziny sztuki, mającej swą historię i bogaty dyskurs, które umieszczam w centrum moich rozważań

T.W. Adorno, Filozofia nowej muzyki, przeł. F. Wayda, Warszawa 1974 , s. 179
Przyjemność płynąca ze słuchania Nowej Muzyki nie należała do jej koncepcji; Nowa Muzyka raczej nie powinna się podobać, skoro „wzięła na swe barki całą mroczność świata i całą jego winę. Swe jedyne szczęście widzi w poznaniu nieszczęścia”’3. Filozof napiętnował przyjemność jako z gruntu obcą nowoczesnej muzyce, zmieniającą ją w używkę, towar, sztukę konsumentów, a zatem domenę krytykowanego przez Adorna przemysłu kultury. Artystycznie i społecznie ambitna Nowa Muzyka miała stawiać sobie i swoim słuchaczom wyższe cele.

Filozof nałożył tabu sensualne również na doświadczenie estetyczne. W jego teorii delektowanie się muzyką nowoczesną nie przystało dojrzałemu odbiorcy, który nie powinien był dać się zwieść pozornej przyjemności sztuki: „Dysonans, znak wszelkiej moderny, również w jego optycznych ekwiwalentach, dopuszcza powabną zmysłowość, transfigurując ją w jej antytezę: ból - estetyczny prafenomen ambiwalencji”" . Nawet tam, gdzie mowa jest o „rozkoszy dysonansów", nie ma ona charakteru afirmacji i przypomina satysfakcję zbuntowanego dziecka wskakującego

3 Ibidem, s. 180

4 T.W. Adorno, Teoria estetyczna, przeł. K. Krzemieniowa, Warszawa 1994, s. 29. 
w świeżo wypranym ubranku do brudnej kałuży na przekór rodzicom ${ }^{5}$.

Wyrosłe na gruncie Adornowskiej dialektyki negatywnej przekonanie, że wartościowe działanie twórcze nie może być afirmacją status quo, lecz jego bezwzględną negacją, przez dekady wspierało rozwój estetyk awangardowych w Nowej Muzyce, nadając im sens krytyki społecznej6. Brak bezpośredniej przyjemności był funkcją tej krytyki i zdefiniował recepcję Nowej Muzyki, która w obiegowym przekonaniu dominuje po dziś dzień.

W drugiej dekadzie XXI wieku kompozytorzy i teoretycy związani ze sceną Nowej Muzyki zaczęli jednak podważać uniwersalną ramę estetyki negatywnej. Katalizatorem przemian okazała się rewolucja cyfrowa oraz jej konsekwencje w postaci zwrotu treściowo-estetycznego i konceptualnego w Nowej Muzyce, które opisał niemiecki filozof Harry Lehmann ${ }^{7}$. $\mathrm{Na}$ polu muzyki brawurowej dekonstrukcji filozofii Adorna dokonał kompozytor Johannes Kreidler. $\mathrm{W}$ trwającym siedem godzin konceptualnym teatrze muzycznym Audioguide (2014) ośmieszył wypracowany przez frankfurtczyka paradygmat Nowej Muzyki ${ }^{8}$. Kreidler dokonał krytyki Adorna poprzez negację negacji, a zatem afirmację wszystkiego, co Adorno napiętnował: od popkultury, nowoczesnych technik reprodukcji dźwięku, przez konkretny charakter relacji Nowej Muzyki ze światem i społeczeństwem, aż po feminizm i pornografię. Utwór ten oparty był na strategii krytycznej, zdefiniowanej przez innego kompozytora i teoretyk kultury Patricka Franka jako hiperafirmacja, która jego zdaniem przejęła we współczesnej sztuce awangardy funkcje krytyczne Adornowskiej negacji.

„Więcej rozkoszy daje dysonans niż konsonans: pozwala to odpłacić hedonizmowi miarką za miarkę. To, co tnące, dynamicznie wyostrzone, rozróżnione w sobie i odmienne od wszelkiego rodzaju afirmatywności, staje się podnietą; ta podnieta zaś w tym samym stopniu co odraza do pozytywnej głupoty kieruje nową sztukę do krainy niczyjej, namiastki zamieszkałej Ziemi”. Ibidem, s. 75.

6 T.W. Adorno, Dialektyka negatywna, przeł. K. Krzemieniowa Warszawa 1986.

H. Lehmann, Rewolucja cyfrowa w muzyce. Filozofia muzyki, przeł. M. Pasiecznik, Warszawa 2016 oraz H. Lehmann, Muzyka konceptualna jako katalizator zwrotu treściowo-estetycznego $w$ nowej muzyce, przekł. zbiorowy, „Glissando” 2013 t. 22, s. 89-105.

8 Por. M. Pasiecznik, Porno Adorno, „Didaskalia” 2014 t. 123, s. 9699. http://archiwum.didaskalia.pl/123 pasiecznik.htm (22.08.2020).

9 P. Frank, Negation, Affirmation, Hyperaffirmation. Zum Stand aktueller Kritik, „Neue Zeitschrift für Musik” 2016 nr 5, s. 16-20.
Krytyka myśli filozoficznej Adorna w kręgu twórców Nowej Muzyki jest dziś zjawiskiem niemal powszechnym i dotyczy wielu aspektów teorii frankfurtczyka, w tym wspomnianego braku przyjemności, co najlepiej uwidocznił niemiecki kompozytor Neo Hülcker w serii audiowizualnych utworów ASMR. W tym artykule wyjaśnię, w jaki sposób Neo Hülcker przełamuje dominujący sposób słuchania Nowej Muzyki, afirmując wypartą z niej przyjemnośćc ${ }^{10}$.

$$
* * *
$$

Neo Hülcker (ur. 1987) to kompozytor-performer, który w swej twórczości koncentruje się na muzyce rozumianej jako antropologiczne studia nad życiem codziennym ${ }^{11}$. Jego kompozycje często mają charakter sytuacyjny, istnieją $\mathrm{w}$ formie instalacji performatywnych, działań i interwencji w różnych przestrzeniach publicznych. Artyst(k)a studiował(a) kompozycję u Dietera Macka i Haralda Muenza w Musikhochschule w Lubece, a także u Manosa Tsangarisa i u Franza Martina Olbrischa w Hochschule für Musik Carl Maria von Weber w Dreźnie (dyplom 2013) ${ }^{12}$. W 2014 roku był(a) stypendyst(k)ą Junge Akademie w Akademie der Künste w Berlinie.

Spośród licznych działań artystycznych bodaj największą uwagę zwróciły prace Neo Hülckera wykorzystujące w kontekście Nowej Muzyki internetową subkulturę ASMR. Neo Hülcker jest współzałożycielem kanału feminist ASMR na YouTube (we współpracy ze Stellanem Veloce i Katie Lee Dunbar), a także kanału ASMR studio Berlin (we współpracy z zespołem mam.manufaktur für aktuelle musik). Sam działa jako artysta ASMR pod pseudonimem Thousand Tingles ${ }^{13}$.

${ }_{10} \mathrm{O}$ paradoksach wynikających z aktywności Adornowskiego paradygmatu percepcji Nowej Muzyki pisałam w kontekście kontrowersji dotyczącej planu wykorzystania przez Deutsche Bahn utworów „muzyki atonalnej” do odstraszania narkomanów ze stacji berlińskiego metra. Por. Monika Pasiecznik, Muzyka atonalna jest dla wszystkich, „Notes na 6 tygodni” 2018 t. 121, https://www.nn6t. pl/2018/12/15/muzyka-atonalna-jest-dla-wszystkich / (30.12.2019).

11 https://www.neohuelcker.de/ (26.03.2019).

12 Wówczas jeszcze jako Neele Hülcker - artystka przeszła operację zmiany płci z żeńskiej na męską i występuje dziś jako Neo Hülcker. W dalszej części tekstu, zgodnie z życzeniem artysty, stosuję formę męską bez względu na to, w którym okresie powstał dany utwór.

13 https://www.youtube.com/channel/UC2uSyRU9XHgSpr4eAs19UPA (26.03.2019); https://www.youtube.com/channel/UCG2RtQL6Y3KVuIOwy5Z9R2g (26.03.2019); https://www.asmryourself. $\mathrm{com} /(26.03 .2019)$. 
ASMR to skrótowiec od Autonomous Sensory Meridian Response. Termin został ukuty przez Amerykankę Jennifer Allen, która w 2010 roku założyła stronę asmr-research.org ${ }^{14}$. Opisała na niej zjawisko, które zaobserwowano kilka lat wcześniej ${ }^{15}$. ASMR powstało w Internecie i rozwija się na takich kanałach jak YouTube, gdzie szybko przekształciło się w potężną subkulturę internetową.

Istotą zjawiska jest przyjemne uczucie mrowienia spowodowane specyficznymi bodźcami słuchowymi, wzrokowymi i dotykowymi. Paleta tych bodźców jest rozległa, często są to rozmaite szmery, delikatne stukanie, na przykład paznokciami, i inne odgłosy. $\mathrm{Na}$ niezliczonych filmach, jakie można znaleźć na YouTube, artyści ASMR starają się wywołać u słuchacza owo mrowienie, używając głosu (zazwyczaj amplifikowanego szeptu), dotykając przedmiotów (na przykład mikrofonu za pomocą pędzelka), a także jedząc, głaszcząc zwierzęta i odgrywając rozmaite role, na przykład fryzjera lub lekarza. Zjawisko niemal od początku swego istnienia jest przedmiotem zainteresowania neuropsychologów, dla których pozostaje jednak nadal zagadką. Bardzo trudno jest je badać, ponieważ reakcja na ASMR nie jest powszechna i opiera się na indywidualnej wrażliwości na bodźce wzrokowe, słuchowe i dotykowe. Istnieją jednak analizy mówiące, że ASMR odwołuje się do zakodowanych $\mathrm{w}$ mózgu pozytywnych skojarzeń $\mathrm{z}$ dzieciństwa lub do działań odbieranych jako przyjemne, i wyzwala wspomnienia ukryte gdzieś głęboko w pamięci, takie jak na przykład usypianie przez matkę lub inną kochającą osobę. Zdaniem naukowców oglądanie filmów ASMR najprawdopodobniej „wyłącza” te części mózgu, które odpowiadają za stres lub lęk, uruchamia zaś ośrodki przyjemności ${ }^{16}$.

W wielu filmach ASMR rozmaite dźwięki, szmery i odgłosy stają się fetyszami, narzędziami przyjemności. Taki ASMR to swoisty noise porn: wyjęty ze swego naturalnego kontekstu, perwersyjnie wyeksponowany, amplifikowany i zapętlony szmer wprowadza ludzi

\footnotetext{
14 Dziś strona ta nosi nazwę ASMR University. Jest na niej udokumentowana historia ASMR, są też gromadzone badania naukowe dotyczące ASMR. Zobacz https://asmruniversity.com (16.10.2019).

15 https://asmruniversity.com/history-of-asmr/ (16.10.2019).

16 B.C. Lochte i in., An fMRI Investigation of the Neural Correlates Underlying the Autonomous Sensory Meridian Response (ASMR), „BioImpacts : BI” 2018 t. 8 nr 4, https://www.ncbi.nlm.nih.gov/pmc/ articles/PMC6209833/ (23.03.2020).
}

W stan zwany czasem „orgazmem mózgu”17. Przyjemne mrowienie nie musi mieć jednak charakteru erotycznego; ASMR często oznacza po prostu uczucie głębokiego relaksu i spokoju ${ }^{18}$.

Działania z ASMR Neo Hülcker rozpoczął performansem Copy!, wykonanym w 2014 roku we Fluxus+ Museum w Poczdamie. W tym samym roku odbył się także inny performans zatytułowany ASMR Yourself ${ }^{9}$. W kolejnych latach Hülcker występował solo i razem z innymi artystami m.in. w Akademie der Künste, w klubie Ausland oraz w teatrze HAU 1 w Berlinie, na Letnich Kursach Nowej Muzyki w Darmstadcie, w PACT Zollverein w Essen, w hörraum.1 Witten, w Bastard Assignments w Londynie i na Münchner Kammerspiele - prezentując swoje prace ASMR zarówno na żywo w formie performansu, jak i na antenie stacji HR2 Kultur. W 2017 roku na Międzynarodowym Festiwalu Muzyki Współczesnej „Warszawska Jesień" hamburski decoder ensemble wykonał ponadto utwór koncertowy pod tytułem ASMR Contemporary Music Ensemble [Tapping] [Scratching] [Brushing] [Whispering] ${ }^{20}$.

Wśród utworów wykorzystujących zjawisko ASMR odrębną grupę stanowią filmy, w których Hülcker nawiązuje do muzyki innych kompozytorów. Są to:

- Helmut Goes ASMR [Whispering] [German] [Birdman] [Re-Enactment] ${ }^{21}$;

- ASMR Tutorial: How to Play "Pression" by Helmut Lachenmann ${ }^{22}$;

- ASMR Tutorial: How to Play Mark Andre ${ }^{23}$;

- ASMR Unwrapping Piano \& Mark Andre iv11 $a^{24}$;

- Peter Ablinger: weiss/weisslich 3 - [super soft $A S M R]^{25}$.

17 P. Etchells, ASMR and 'Head Orgasms': What's the Science behind It?, „The Guardian” 20.01.2016, https://www.theguardian.com/ science/head-quarters/2016/jan/08/asmr-and-head-orgasms-whatsthe-science-behind-it (23.03.2020).

18 E.L. Barratt, N.J. Davis, Autonomous Sensory Meridian Response (ASMR): a Flow-Like Mental State, „PeerJ” 26.03.2015, t. 3, https://www.ncbi.nlm.nih.gov/pmc/articles/PMC4380153/ (23.03.2020).

19 Dokumentacja projektu ASMR Yourself dostępna na stronie https://www.facebook.com/ASMRyourself/ (23.03.2020).

20 Archiwum występów można przejrzeć na stronie internetowej artysty: https://www.neohuelcker.de/ (23.03.2020).

${ }^{21}$ https://www.youtube.com/watch?v=dvhETAXgIs8 (26.03.2019).

22 https://www.youtube.com/watch?v=Ke41xtDtkhc (26.03.2019).

${ }^{23} \mathrm{https} / / /$ www.youtube.com/watch? $\mathrm{v}=\mathrm{mGF} 8 \mathrm{U} 02 \mathrm{gEjQ}$ (26.03.2019).

$24 \mathrm{https} / / /$ www.youtube.com/watch? $\mathrm{v}=\mathrm{KgEyB} 63 q \mathrm{q} \mathrm{sM}$ (26.03.2019).

25 https://www.youtube.com/watch? $\mathrm{v}=$ goBmCmDVo0 (26.03.2019). 
To właśnie na tych utworach skoncentruję się w niniejszym tekście.

Wykorzystując ASMR w kontekście muzycznym, Neo Hülcker stawia kilka pytań: „W jaki sposób ASMR może stać się materiałem kompozycji? Co się stanie, gdy te dwa światy: muzyka współczesna i ASMR się spotkają? Czy współczesna muzyka może być ASMR? Czy ASMR może być muzyką współczesną?"26.

Odpowiedź na pytanie o materiał kompozycji wydaje się prosta: Nowa Muzyka i ASMR posługują się podobnym materiałem dźwiękowym. Kompozytorzy Nowej Muzyki, tak jak artyści ASMR, fetyszyzują rozmaite szmery wytwarzane na instrumentach akustycznych za pomocą tak zwanych rozszerzonych technik gry (extended playing techniques). Adaptacja szmerów w Nowej Muzyce instrumentalnej jest konsekwencją rozwoju muzyki konkretnej i elektronicznej, które doprowadziły do „umuzycznienia” dźwięków pochodzących spoza świata muzyki klasycznej i włączenia do Nowej Muzyki rozmaitych „nieinstrumentalnych” odgłosów. Na szeroką skalę owej adaptacji dokonał kompozytor Helmut Lachenmann, rozwijając bogaty zasób niekonwencjonalnych brzmień i nazywając swój język muzyczny właśnie musique concrète instrumentale.

Podczas gdy materiał dźwiękowy Nowej Muzyki i ASMR jest podobny, jego znaczenie różni się w obu tych kontekstach: dla odbiorcy ASMR szmery są źródłem przyjemnego mrowienia, w Nowej Muzyce zaś mają przede wszystkim irytować. Różnicę tę pokazuje film Helmut Goes ASMR [Whispering] [German] [Birdman] [Re-Enactment], w którym Neo Hülcker rekonstruuje fragment wywiadu z Helmutem Lachenmannem. Wywiad odbywa się szeptem, w charakterystycznej konwencji ASMR. Kompozytor(ka) wciela się w Lachenmanna, zaś pytania zadaje tajemnicza postać w masce gołębia. Oto fragment ich dialogu:

Dziennikarz: Panie Lachenmann, jest Pan jednym z najbardziej radykalnych kompozytorów ostatnich czterdziestu lat, który pozostaje radykalny i przez to trudny do zrozumienia, ponieważ - i to jest zwykle argument przeciwko nowości,

${ }^{26}$ N. Hülcker, komentarz do utworu ASMR Contemporary Music Ensemble [Tapping] [Scratching] [Brushing] [Whispering], książka programowa festiwalu „Warszawska Jesień” 2017, http://www.warszawska-jesien.art.pl/wj2017/program-i-bilety-2017/utwory/1145106598 (23.03.2019). przeciwko Nowej Muzyce - muzyka ta nie podbija serca, ale w najlepszym razie głowę. Który organ jest, Pana zdaniem, odpowiedzialny za odbiór muzyki?

Helmut Lachenmann: Pomiędzy sercem i głową nie należy stawiać żadnej wapiennej ściany, tam, gdzie myśli i uczucia rozpadają się, powtarzam po raz kolejny, znaczy to, że obie sfery są słabo rozwinięte. W końcu nie tylko przy okazji mojej opery przekonałem się, że moja trudna muzyka wielokrotnie słuchana, ale nie powierzchownie, jest w stanie dotrzeć do serca. Kluczowa w tym kontekście wydaje mi się irytacja. Jak radzimy sobie z irytacją? Czy sprzeciwiamy się jej, woląc pozostać na naszym dobrze już znanym estetycznym terenie, czy pozwalamy się sprowokować przez to, co nieznane? W końcu prowokować, pobudzać, zapraszać do polemiki oznacza wychylać się poza nasze horyzonty ${ }^{27}$.

Następnie gołąb ogłasza, że znaczenie „irytacji” i „prowokacji” zostanie zilustrowane przykładami dźwiękowymi. Neele Hülcker bierze do rąk skrzypce i, przesuwając smyczkiem po pudle rezonansowym, zaczyna produkować ledwie słyszalne szmery.

Przytoczony fragment wywiadu $\mathrm{z}$ Lachenmannem jest niezwykle interesujący, ukazuje bowiem konstytutywny dla Nowej Muzyki konflikt oczekiwań, który w kontekście ASMR wydaje się jednak dość osobliwy. Ów konflikt zawiera się w kilku obiegowych przekonaniach wyrażonych w tym wywiadzie przez dziennikarza, a mianowicie, że 1) Lachenmann to kompozytor radykalny; 2) jego muzyka jest adresowana do głowy, a nie do serca, inaczej mówiąc: można ją co najwyżej pojąć intelektualnie, nie budzi jednak

27 „Journalist: Herr Lachenmann, Sie gehören ja zu den radikalsten Komponisten der letzten 40 Jahre, was immer radikal heißt, geht als schwer verständlich, weil - und ist das ja meist das Argument gegen das Neue, gegen die Neue Musik - ihre Musik nicht das Herz, sondern allenfalls den Kopf erreiche. Welches Organ ist dann ihrer Meinung nach zuständig für Musik?

Helmut Lachenmann: Zwischen Herz und Kopf sollte möglichst keine Kalkwand eingezogen sein, wo Denken und Fühlen auseinanderfallen, so sag ich immer wieder, ist beides unterentwickelt. Ich habe immerhin übrig nicht nur bei meiner Oper die Erfahrung gemacht, dass meine Kopflastige Musik beim vielen Hören und bestimmt nicht bei dem Oberflächlichsten, auch das Herz erreicht.

Das Stichwort bei diesem Zusammenhang heißt vielleicht Irritation. Wie gehen wir mit Irritationen um? Wären wir und dagegen und bleiben wir lieb bei unseren gewonnenen ästhetischen Bereich oder lassen wir uns von der Ungewohnten provozieren? Schließlich heißt provozieren, hervorrufen, einladen, über unsere Horizonte ausschauen". Por. https://www.youtube.com/watch?v=dvhETAXgIs8 (26.03.2019) 
w słuchaczu emocji, nie daje przyjemności; 3) Nowa Muzyka zniechęca do siebie słuchacza. Odpowiedzi Lachenmanna są równie znamienne: 4) kompozytor uzasadnia swoją twórczą postawę chęcią prowokowania i irytowania słuchacza, przypisując im właściwości poszerzenia horyzontów poznawczych.

Lachenmann zbudował swoją teorię estetyczną na przekonaniu, że Nowa Muzyka jest formą doświadczenia egzystencjalnego, które możliwe jest jednak za cenę utraty wewnętrznego spokoju. Oprócz „irytacji” i „prowokacji”, inne kluczowe pojęcia w estetyce Lachenmanna to „opór”, „odmowa” i „krytyka”28. Owemu doświadczeniu i poznaniu służą środki muzyczne, takie jak wszelkiego rodzaju szmery, świsty i hałasy, drapanie i głuche stuknięcia w pudło rezonansowe, jednym słowem: rozmaite szumy, które zastępują konwencjonalnie rozumiane "dźwięki muzyczne” i prowokują przyzwyczajenia słuchowe. Lachenmann definiuje piękno jako „odrzucenie przyzwyczajeń”, co pozwala mu kultywować możliwości instrumentów $\mathrm{w}$ zakresie nietypowych brzmień musique concrète instrumentale ${ }^{29}$.

Muzyka Lachenmanna jest więc nie tylko prowokacją dla przyzwyczajeń słuchacza, ale także wyrazem ciekawości kompozytora dotyczącej wcześniej nieznanych możliwości instrumentów orkiestry. Zasadniczo jednak kompozytor nie mówi o uczuciu przyjemności, środki musique concrète instrumentale nie służą uspokajaniu, relaksowaniu ani tym bardziej wywoływaniu przyjemnego mrowienia.

Odtwarzając dialog z Lachenmannem w kontekście ASMR, Neo Hülcker problematyzuje właśnie ten aspekt jego teorii. Inscenizując wywiad w konwencji ASMR, dekonstruuje krytyczny potencjał jego muzyki i wydobywa z niej rzekomo nieobecny wymiar przyjemności. Pomimo programowej irytacji i prowokacji, „trudna” muzyka Lachenmanna może nieoczekiwanie stać się źródłem przyjemnych doznań zmysłowych.

Zamiar ten widać w filmie ASMR Tutorial: How to Play „Pression” by Helmut Lachenmann, w którym Hülcker skupia się jeszcze bardziej na tłumionej przyjemności słuchania Nowej Muzyki, inscenizując lekcję poświęconą jednemu z najbardziej wirtuozowskich

28 Wcześniej Lachenmann mówił też o „negacji” i „muzyce negatywnej”. Por. H. Lachenmann, Musik als existentielle Erfahrung. Schriften 1966-1995, red. J. Häusler, Wiesbaden 2004, s. 108.

29 Ibidem. utworów Nowej Muzyki. W swojej kompozycji Pression Lachenmann użył całej gamy rozszerzonych technik gry, które w filmie Hülckera są nazywane „ładnymi i okrągłymi” („nice and round”). Muzyk prezentuje „ładne nowe techniki” („nice new techniques”), jak na przykład bezdźwięczne przesuwanie smyczkiem po mostku lub strunniku oraz pocieranie strun otwartą dłonią lub paznokciami. Szeptem radzi, by ćwiczyć te techniki piętnaście, dwadzieścia minut każdego dnia, wtedy zabrzmią „naprawdę ładnie”.

Film ten można interpretować jako podszytą ironią krytykę klasycznie pojmowanego „pięknego dźwięku", co oczywiście koresponduje ze stanowiskiem Lachenmanna. Wydaje się jednak, że ukazanie rozszerzonych technik gry w kontekście ASMR powoduje przede wszystkim odczarowanie środków Nowej Muzyki poprzez unieważnienie ich krytycznej mocy z perspektywy ASMR Lachenmannowskie efekty dźwiękowe nie są już „odpychające”, „irytujące” czy "prowokujące”, ale „ładne i okrągłe”, krótko mówiąc: przyjemne.

Podobnie jest z twórczością Marka Andre, kompozytora i ucznia Lachenmanna, a także kontynuatora jego linii estetycznej, który rozwinął środki dźwiękowe swego mistrza, a także poszerzył ich semantykę ${ }^{30}$. Andre, nazywany „metafizykiem wśród kompozytorów”, znany jest ze swych religijnych inspiracji. W wielu kompozycjach podejmuje tematykę eschatologiczną, stroniąc jednak od częstej we współczesnej muzyce religijnej łatwo dostępnej żarliwej emocjonalności. Religijność, duchowość i metafizyka muzyki Marka Andre oznaczają raczej radykalizację środków, niekiedy skrajną ascezę bliską wyrzeczenia się dźwięku poprzez zastąpienie go ciszą, której sens polega na chęci pełnego zwrócenia się w stronę tego, co Niemcy nazywają Jenseits - poza, gdzie indziej - po tamtej stronie. Kompozytor „poszukuje metafizyki tu i teraz, w czasie rzeczywistym i w bardzo fizyczny sposób. Nie ogłasza radosnej nowiny, ale widzi swoje zadanie $\mathrm{w}$ radykalnym, prowokującym do myślenia badaniu rzeczy ostatecznych za pomocą środków muzycznych"31.

${ }^{30}$ „Musik-Konzepte. Neue Folge”, Heft 167: Mark Andre, red. U. Tadday, München 2015.

31 J. Spinola, Das musikalische Jenseits. Der Komponist Mark Andre, „Die Zeit“ 8.03.2014, https://www.zeit.de/2014/10/komponist-mark-andre (21.04.2019) 
W filmie ASMR Unwrapping Piano \& Mark Andre iv11a Neo Hülcker opracowuje miniaturę fortepianową Marka Andre. Rozpoczynający wideo szelest powoli zdejmowanego $\mathrm{z}$ fortepianu pokrowca buduje zmysłowe napięcie, które osiąga kulminację z chwilą otwarcia klapy fortepianu i uderzenia w klawisze. Cała kompozycja Andre to miarowo powtarzane dwa dźwięki w najwyższym i najniższym rejestrze fortepianu, których częstotliwość i barwę zniekształca głuche dudnienie mechanizmu młoteczkowego. Surowe i wyobcowane brzmienie instrumentu uruchamia jednak mikrokosmos rezonansu ${ }^{32}$.

To, co dla Marka Andre oznacza metafizykę, a co Jeffrey Arlo Brown scharakteryzował jako „post-War-traumatized-German-music", dla Hülckera staje się fetyszem, źródłem rozkoszy ${ }^{33}$.

Jeszcze inny efekt przynosi interpretacja muzyki Petera Ablingera, kompozytora znanego z konceptualnego podejścia do dźwięku, a zwłaszcza do szumu i szmeru ${ }^{34}$. W swych licznych utworach z pogranicza muzyki, instalacji dźwiękowej i performansu, austriacki twórca wypracował szczególne podejście do słuchania, któremu nadał centralną rolę w swej praktyce artystycznej: „Moim materiałem nie jest dźwięk. Moim materiałem jest słyszalność"35. Słuchanie jest dla Ablingera procesem kognitywnym, nie zaś czysto zmysłowym: „Staram się uczynić percepcję percypowalną, by jedna osoba odbierała dźwięk tak, jakby to były dwie różne osoby" ${ }^{36}$. Ablinger projektuje rozmaite sytuacje odbioru, które mają za zadanie wyobcować słuchanie i wyostrzyć percepcję. Słuchanie służy doskonaleniu siebie, a nawet samopoznaniu ${ }^{37}$.

Zjawiskiem dźwiękowym szczególnie interesującym dla Ablingera jest szum, który definiuje on

\footnotetext{
32 https://soundcloud.com/mark-andre/iv11-3-miniaturen-furklavier (26.03.2019).

${ }^{3}$ J.A. Brown, Interview with Mark Andre, „VAN Magazine" 7.06.2017, https://van-us.atavist.com/mark-andre-interview (21.03.2019).

34 O rozróżnieniu między szumem i szmerem por.: M. Pasiecznik, Wyjść od szumu i wyodrębnić z niego ksztalty. Wywiad z Peterem Ablingerem, „Ruch Muzyczny” 2009 nr 2, https://pasiecznik.wordpress.com/2008/11/25/peter-ablinger/ (23.03.2020).

35 https://ablinger.mur.at/txt_polski.html (23.03.2020).

36 https://ablinger.mur.at/engl.html (23.03.2020).

37 Kompozytor opowiadał o tym na spotkaniu z publicznością w Warszawie w 2009 roku. Zapis tego spotkania, które miałam przyjemność moderować, ukazał się na łamach „Ruchu Muzycznego”. Por. M. Pasiecznik, Wyjść od szumu..., op. cit.
}

jako „pojęcie”, nie zaś „doświadczenie” ${ }^{38}$. Szum jest ponadto kategorią przestrzenną, rzeźbiarską, można z niego wydobywać kształty ${ }^{39}$. Jest materią, w której się rzeźbi, nie zaś impulsem, który wywołuje reakcje psychosomatyczne. W serii utworów zatytułowanych Speaking Piano Ablinger modeluje biały szum, z którego stopniowo zaczynają wyłaniać się słowa ${ }^{40}$. Chodzi tu o sposób, w jaki działa ludzki mózg, projektując określone znaczenia werbalne na abstrakcyjny szum. Ablingera interesuje percepcja zjawisk akustycznych, jednak nie jest to percepcja stricte sensualna. Tego rodzaju działania nie mają nic wspólnego z cielesną przyjemnością.

Inna seria utworów Petera Ablingera zatytułowana jest weiss/weisslich. Jeden z nich opracował Neo Hülcker. Na filmie Peter Ablinger: weiss/weisslich 3 [super soft ASMR] widzimy pięciu wykonawców w perukach zasłaniających ich twarze ${ }^{41}$. Artyści pocierają delikatnie włosy obiema dłońmi, produkując ledwie słyszalny szelest.

Tytuł serii Ablingera - biały/białawy - nawiązuje do granic ludzkiej percepcji w możliwości rozróżnienia pomiędzy ciszą i dźwiękiem, kolor zaś symbolizuje ten rodzaj szumu, który zawiera w sobie wszystkie dźwięki (niczym białe światło, które zawiera w sobie wszystkie kolory). „Białe to jednocześnie wszystko i nic" ${ }^{\prime 2}$

Mówiąc, iż „nie jesteśmy dostatecznie wyćwiczeni w rozpoznawaniu tych różnic", Ablinger przygotowuje słuchacza na swoistą lekcję słuchania ${ }^{43}$. Neo Hülcker zaś odwraca o sto osiemdziesiąt stopni tę perspektywę, dodając element wizualny. Dotykanie włosów to nie tylko źródło szmerów, ale także powszechnie znany fetysz. Połączenie ledwie słyszalnego szelestu z gestem głaskania po głowie służy czemuś zupełnie innemu niż procesy kognitywne: generuje zmysłową przyjemność.

Neo Hülcker zapewne nie przypadkiem czyni bohaterami swoich filmów ASMR takich kompozytorów, jak Mark Andre, Helmut Lachenmann czy Peter Ablinger. Zwłaszcza Lachenmann jest dla Nowej

\footnotetext{
38 Ibidem

39 Ibidem.

${ }^{40}$ https://ablinger.mur.at/speaking_piano.html (23.03.2020).

41 https://www.youtube.com/watch? $\mathrm{v}=$ goBmCmDVo0 (26.03.2019).

${ }^{42}$ Cyt. za: M. Pasiecznik, Wyjść od szumu..., op. cit.

43 Ibidem.
} 
Muzyki postacią emblematyczną. Wypracowany przez niego język dźwiękowy, oparty na rozszerzonych technikach gry, ma dziś status lingua franca Nowej Muzyki, zaś niezwykle spójna teoria estetyczna Lachenmanna przez ostatnie dekady silnie kształtowała świadomość tej sceny. Dlatego dekonstrukcja estetyki Lachenmanna, kontynuowanej m.in. przez Marka Andre, za pomocą ASMR może bez większych trudności objąć Nową Muzykę jako taką. Nawet z pozoru opozycyjna postawa artystyczna Petera Ablingera wyrasta z dyskursu Nowej Muzyki i konstytutywnego dla niego kognitywizmu.

W serii muzycznych filmów ASMR Neo Hülcker dekonstruuje więc nie tylko estetykę muzyki Helmuta Lachenmanna, ale i całą Adornowską wykładnię Nowej Muzyki. Dotykając tabu przyjemności w Nowej Muzyce, kompozytor przełamuje nadal dominujący sposób jej słuchania i rozumienia. Wydobywa z muzyki Helmuta Lachenmanna, Marka Andre i Petera Ablingera stłumioną, stanowiącą tabu przyjemność i udowadnia, że nawet najbardziej radykalne estetyki Nowej Muzyki mogą się podobać. Za cenę uchylenia jej krytycznej czy poznawczej mocy artysta odsłania przestrzeń cielesnej represji i faktycznego wyparcia z Nowej Muzyki jednej z jej fundamentalnych właściwości, a mianowicie psychosomatycznego oddziaływania dźwięków. Koncentrując się na przyjemnym doświadczeniu zmysłowym, na radości płynącej z słuchania wszystkich dźwięków i hałasów, Neo Hülcker rozsadza koncepcję Nowej Muzyki od środka ${ }^{44}$.

$$
* * *
$$

Piętnowanie przyjemności w Nowej Muzyce nie jest wyjątkiem; zjawisko to można dostrzec również w innych dziedzinach współczesnej sztuki i kultury Zachodu, w których cielesna, zmysłowa przyjemność jest często marginalizowana i przeciwstawiana poznaniu intelektualnemu. XX-wieczna filozofia

${ }^{44}$ Tematykę stabuizowanej przyjemności słuchania muzyki posttonalnej poruszał też Andrew Mead w tekście One Man's Signal Is Another Man's Noise: Personal Encounters with Post-Tonal Music. W swym studium autor skoncentrował się jednak na doświadczeniu słuchacza, nie zaś na tym, jakie konsekwencje owo doświadczenie może mieć w samym pojęciu muzyki, zwłaszcza Nowej Muzyki. Por. A. Mead, One Man's Signal Is Another Man's Noise: Personal Encounters with Post-Tonal Music, [w:] The Pleasure of Modernist Music. Listening, Meaning, Intention, Ideology, red. A. Ashby, Rochester 2004, s. $259-274$.
Zachodu, zdominowana przez racjonalizm i idealizm, rzadko dostrzega wartość płynącą z doświadczenia przyjemności, mimo iż na przestrzeni wieków, od czasów Demokryta, wykształciła się bogata tradycja, przypisująca temu doświadczeniu ogromną wartość ${ }^{45}$.

Amerykański filozof Richard Shusterman, autor książki Myślenie ciała. Eseje z zakresu somaestetyki, powziął zamiar przekonania czytelników o kulturowej wartości przyjemności. W eseju Come Back to Pleasure prześledził historię przyjemności w sztuce i ukazal przełomowy moment $\mathrm{w}$ historii estetyki, który wpłynął na sztukę XX wieku.

Upadek prestiżu przyjemności $\mathrm{w}$ najnowszej estetyce można zobaczyć w jej krytyce w myśli niemieckiej XX wieku. Nie godząc się na wartość ,jedynie artystycznej przyjemności", Martin Heidegger podkreśla, że funkcją definiującą sztukę ,jest wprowadzanie w czyn prawdy”. Hans-Georg Gadamer również atakuje bezpośrednie przyjemności doświadczenia estetycznego, nalegając zamiast tego na sens i prawdę sztuki, najwyraźniej zakładając, że wartości te są w jakiś sposób sprzeczne z bardziej bezpośrednimi przyjemnościami.

Konflikt tych wartości jest jeszcze wyraźniejszy w twórczości Theodora Adorna [...], który zdecydowanie przeciwstawia sobie artystyczną przyjemność i poznanie: „Ludzie lubią dzieła sztuki tym mniej, im więcej o nich wiedzą, i na odwrót”. W konkurencji o wartości, dla Adorna jest jasne, że przyjemność musi zostać poświęcona dla prawdy: „W fałszywym świecie hedonizm jest fałszywy. Odnosi się to również do przyjemności artystycznej”. „Sztuka nie powinna od razu dawać przyjemności... Krótko mówiąc, przekonanie, że przyjemność jest istotą sztuki, musi zostać wyrzucone za burtę... To, czego dzieła naprawdę od nas wymagają, to wiedza lub, lepiej, kognitywna zdolność do sprawiedliwego osądzania”46.

Zdaniem Shustermana istnieją dwa dogmaty, które wymagają rewizji: pierwszy to przekonanie, że przyjemność jest banalna i płytka - innymi słowy: nie jest poważna. Amerykanin odrzuca ten dogmat, przywołując argumenty filozofów działających przed Heglem, a także postheglowską teorię ewolucji, które

45 Myśl hedonistyczną rozwijali tacy myśliciele, jak m.in. Epikur, Filodemos, Arystoteles, Lukrecjusz, św. Tomasz z Akwinu, Diderot, Michel de Montaigne, Baruch Spinoza, Friedrich Nietzsche, Roland Barthes i in. Por. R. Shusterman, Come Back to Pleasure, 2010, "Naked Punch" http://www.nakedpunch.com/articles/59 (26.03.2019).

${ }^{46}$ Ibidem. Ten i kolejne cytaty w tłumaczeniu autorki. 
świadczą o kluczowej, zasadniczej i złożonej roli przyjemności w naszym życiu. Drugi dogmat wzmacnia domniemaną opozycję między przyjemnością z jednej, a znaczeniem i prawdą $\mathrm{z}$ drugiej strony.

Hegel błędnie zakłada, że jeśli szukamy i znajdujemy przyjemność w sztuce, nie możemy również znaleźć prawdy i zrozumienia. Myśliciele postheglowscy, tacy jak Heidegger, Adorno i Danto, wydają się być przejęci tym samym strachem, wyrażonym najgłośniej w twierdzeniu Adorna, że im mniej rozumiemy sztukę, tym większą czerpiemy z niej radość i na odwrót. Błędna opozycja przyjemności i wiedzy opiera się na fałszywym założeniu, że przyjemność jest jakimś rodzajem obezwładniającego uczucia, które nie jest związane z działaniem, przez które się pojawia i dalej odwraca uwagę od tej aktywności przez swoją własną moc. To założenie opiera się z kolei na płytkim empiryzmie, który zrównuje doświadczenie $\mathrm{z}$ biernymi odczuciami, a nie z aktywnością ${ }^{47}$.

Richard Schusterman przekonuje, że przyjemności cielesne nie są zasadniczo złe. Możemy się nimi dzielić $\mathrm{i}$ tworzyć $\mathrm{w}$ ten sposób relacje $\mathrm{z}$ innymi ludźmi. Przyjemność wzmacnia też zaangażowanie $\mathrm{w}$ dane działanie, a tym samym podnosi jego jakość. Dotyczy to $\mathrm{w}$ równej mierze życia i sztuki. Cieszenie się twórczością artystyczną pomaga patrzeć i słuchać uważniej, czyniąc odbiór dzieła głębszym i bardziej satysfakcjonującym, a w konsekwencji wzmacniając zainteresowanie sztuka jako taką.

Dla kompozytora Neo Hülckera przyjemność obcowania z Nową Muzyką wydaje się naturalna i swoiście oczywista. Dzieląc się swoją, opartą na bezpośrednim doświadczeniu cielesnym, afirmatywną interpretacją muzyki Helmuta Lachenmanna oraz innych twórców, takich jak Mark Andre czy Peter Ablinger, wskazuje na ukryty potencjał Nowej Muzyki, który po dziś dzień stanowi ślepą plamkę jej filozofii.

\section{BIBLIOGRAFIA}

Ablinger Peter, [polskie teksty], https://ablinger.mur.at/txt_ polski.html (23.03.2020).

Adorno Theodor W., Dialektyka negatywna, przeł. Krystyna Krzemieniowa, PWN, Warszawa 1986.

\footnotetext{
47 Ibidem.
}

Adorno Theodor W., Filozofia nowej muzyki, przeł. Fryderyka Wayda, PIW, Warszawa 1974.

Adorno Theodor W., Teoria estetyczna, przeł. Krystyna Krzemieniowa, PWN, Warszawa 1994.

ASMR University, https://asmruniversity.com/history-of-a -smr/ (16.10.2019).

Barratt Emma L., Davis Nick J., Autonomous Sensory Meridian Response (ASMR): a Flow-like Mental State, „PeerJ” 26.03.2015, t. 3, https://www.ncbi.nlm.nih.gov/pmc/articles/PMC4380153/ (23.03.2020).

Brown Jeffrey A., Interview with Mark Andre, „VAN Magazine" 7.06.2017, https://van-us.atavist.com/mark-andre-interview (21.03.2019).

Etchells Pete, ASMR and 'Head Orgasms': What's the Science behind It?, „The Guardian” 20.01.2016, https://www. theguardian.com/science/head-quarters/2016/jan/08/ asmr-and-head-orgasms-whats-the-science-behind-it (23.03.2020).

Frank Patrick, Negation, Affirmation, Hyperaffirmation. Zum Stand aktueller Kritik, „Neue Zeitschrift für Musik” 2016 nr 5, s. 16-20. https://www.academia.edu/40384336/Negation_Affirmation_Hyperaffirmation (22.08.2020).

Hülcker Neo, komentarz do utworu ASMR Contemporary Music Ensemble [Tapping] [Scratching] [Brushing] [Whispering], książka programowa festiwalu „Warszawska Jesień” 2017, http://www.warszawska-jesien.art.pl/wj2017/program-i-bilety-2017/utwory/1145106598 (23.03.2019).

Lachenmann Helmut, Musik als existentielle Erfahrung. Schriften 1966-1995, red. Josef Häusler, Breitkopf \& Härtel, Wiesbaden 2004.

Lehmann Harry, Muzyka konceptualna jako katalizator zwrotu treściowo-estetycznego w nowej muzyce, przeł. Tomasz Biernacki, Monika Pasiecznik, Piotr Jan Wojciechowski, Monika Zamięcka, „Glissando” 2013 t. 22, s. 89-105.

Lehmann Harry, Rewolucja cyfrowa w muzyce. Filozofia mu$z y k i$, przeł. Monika Pasiecznik, Fundacja Bęc Zmiana, Warszawa 2016.

Lochte Bryson C., Guillory Sean A., Richard Craig A.H., Kelley William M., An fMRI Investigation of the Neural Correlates Underlying the Autonomous Sensory Meridian Response (ASMR), „BioImpacts : BI” 2018 t. 8, nr 4, https:// www.ncbi.nlm.nih.gov/pmc/articles/PMC6209833/ (23.03.2020).

Mead Andrew, One Man's Signal Is Another Man's Noise: Personal Encounters with Post-Tonal Music, [w:] The Pleasure of Modernist Music. Listening, Meaning, Intention, Ideology, red. Arved Ashby, University of Rochester Press, Rochester 2004. 
„Musik-Konzepte. Neue Folge”, Heft 167: Mark Andre, red. Ulrich Tadday, München 2015.

Pasiecznik Monika, Muzyka atonalna jest dla wszystkich, „Notes na 6 tygodni” 2018 t. 121, https://www.nn6t. pl/2018/12/15/muzyka-atonalna-jest-dla-wszystkich/ (30.12.2019).

Pasiecznik Monika, Porno Adorno, „Didaskalia” 2014 t. 123, s. 96-99, http://archiwum.didaskalia.pl/123_pasiecznik. htm (22.08.2020).

Pasiecznik Monika, Wyjść od szumu i wyodrębnić jego ksztatty. Wywiad z Peterem Ablingerem, "Ruch Muzyczny” $2009 \mathrm{nr} 2$, https://pasiecznik.wordpress.com/?s=ablinger (23.03.2020).

Shusterman Richard, Come Back to Pleasure, 2010, "Naked Punch", http://www.nakedpunch.com/articles/59(26.03.2019).

Spinola Julia, Das musikalische Jenseits. Der Komponist Mark Andre, „Die Zeit“ 8.03.2014, https://www.zeit.de/2014/10/ komponist-mark-andre (21.04.2019).

\section{Linki do stron internetowych oraz do utworów Neo Hülckera:}

https://www.neohuelcker.de/ (26.03.2019). https://www.youtube.com/watch?v=_goBmCmDVo0 (26.03.2019).

https://www.youtube.com/channel/UC2uSyRU9XHgSpr4eAs19UPA (26.03.2019). https://www.youtube.com/channel/UCG2RtQL6Y3KVuIOwy5Z9R2g (26.03.2019). https:// www.asmryourself.com/ (26.03.2019).

https://asmruniversity.com/history-of-asmr/ (16.10.2019).

\section{SUMMARY}

\section{Monika Pasiecznik}

\section{New Music and Pleasure in Neo Hülcker's Audiovisual ASMR Series}

New Music developed in the twentieth century under the influence of Theodor W. Adorno's philosophy. Its sense, according to the philosopher, lies in social criticism, which the composer accomplishes through radical artistic innovation, and the distance from the audience's expectations. The sensual pleasure of sound reception is not included in the concept of New Music, which preferably should not appeal to anybody, as it "took on the shoulders darkness of the world and all its guilt, and sees its only happiness in knowing misery" (Adorno).
In the ASMR series, the German composer Neo Hülcker breaks this paradigm of perception and proposes a radically different interpretation of New Music.

ASMR, or Autonomous Sensory Meridian Response, is a sensation of pleasant tingle, caused by subtle acoustic-haptic phenomena, such as amplified murmurs, whispers, touching objects and materials. Millions of people around the world are watching ASMR videos on YouTube that let them relax nicely.

In such video compositions as ASMR Tutorial: How to Play "Pression" by Helmut Lachenmann, ASMR Tutorial: How to Play Mark Andre or ASMR Unwrapping the Piano \& iv 11a, and Peter Ablinger: weiss/ weisslich 3 - [super soft ASMR] Neo Hülcker investigates the similarity of sound material of illustrative pieces of New Music and ASMR, raising the question of whether New Music can make someone feel tingly. Presenting in the context of ASMR works by Helmut Lachenmann, Mark Andre and Peter Ablinger, Hülcker explores the hidden potential contained in the most radical aesthetics of New Music, namely the suppressed carnal pleasure. The article is an attempt to show the ways how Neo Hülcker redefines the concept of New Music, entering in it the sensual experience of sound.

\section{Keywords}

New Music, pleasure, ASMR, Adorno, Lachenmann, Ablinger, Andre, aesthetics of negation 